\title{
COVID-19 Pandemisi Sürecinde Dijital Platformların Yükseliși: Sinema Değer Zincirindeki Değișim Sinema Endüstrisini Nasıl Etkiler?
}

\section{Hakan Erkılıç}

Mersin Üniversitesi Illetișim Fakültesi

https://orcid.org/0000-0002-0828-3848

erkilichakan@gmail.com

\author{
Senem Duruel Erkilıç \\ Mersin Üniversitesi lletișimim Fakültesi \\ https://orcid.org/0000-0003-2053-4635 \\ sduruelerkilic@gmail.com
}

\section{Öz}

COVID-19 pandemisi dijital platformlar için katalizör ișlevi görmüștür. Sinema salonlarının kapanmasından dolayı stüdyolar, gösterimleri ertelerken bir yandan da kirala \& izle modeli (VoD) ile dijital platformlara yönelmektedirler. Sinema salonlarında gösterim sürecinin atlanarak filmlerin doğrudan dijital platformlarda gösterime girmesi klasik yapım-dağııım-gösterim zincirinin kırılması anlamına gelmektedir. Bu durum yeni bir dikey yapılanmayı ve ișleyiși doğurmaktadır. Yeni Sinema Ișletim Değer Zinciri ağırlık kazanmakta, bu alandaki dönüșüm Yeni Medya Iș Modeli veya Business 2.0 olarak değerlendirilmektedir. Makale, bağlamsal yaklașımla sinema değer zinciri içinde gün geçtikçe yükseliș eğrisi gösteren dijital platformları dünya ve Türkiye özelinde karșılaștırmalı olarak incelemeyi amaçlamaktadır. Küresel sinema endüstrisinde ve Türkiye'deki tartıșmalar ile yasal düzenlemeler makalenin çalıșma çerçevesini çizmektedir. Yöntem olarak bağlamsal yaklașımla sinema değer zinciri, ulusal bir film endüstrisinin kültürel, politik, kurumsal, endüstriyel belirleyicilerinden biri olarak analiz edilmektedir. Bu çerçevede sinema sektörü temsilcileri ile yapmıș olduğumuz derinlemesine görüșme verileri ile ikincil kaynakların (mevzuat, rapor, literatür) inceleme ve analizi yapılacaktır.

Anahtar kelimeler: Sinema Değer Zinciri, VoD, dijital platformlar, COVID-19 pandemisi, sinema salonu

Makale geliș tarihi: 01.03.2021 - Makale kabul tarihi: 15.11.2021

http://ilefdergisi.ankara.edu.tr

ilef dergisi • () 2021 - Özel Sayı • güz/autumn: 99-126

Araștırma Makalesi DOI: 10.24955/ilef.1037981 


\section{The Rise of Digital Platforms in Days of COVID-19}

Pandemic:

How Does the Change in Film Value Chain Affect the Film Industry?

Hakan Erkılıç

Mersin University Faculty of Communication

https://orcid.org/0000-0002-0828-3848

erkilichakan@gmail.com
Senem Duruel Erkıllç Mersin University Faculty of Communication https:/lorcid.org/0000-0003-2053-4635 sduruelerkilic@gmail.com

\section{Abstract}

The COVID-19 pandemic acts as a catalyst for digital platforms. Since movie theatres are closed, studios delay exhibitions, with a tendency toward digital platforms with the VoD model. Skipping the exhibition process and directly exhibiting films on digital platforms means breaking the classical production-distribution-exhibition chain. The New Film Exploitation Value Chain carries weight, and the transformation in this domain is regarded as the New Media Business Model or Business 2.0. This article aims to examine digital platforms showing a positive slope in the cinema value chain, comparing Turkey with the world. The paper focuses on debates within the global film industry and Turkey, and the related legislation. With a contextual approach, the cinema value chain is analysed as one of the cultural, political, institutional, and industrial determinants of the national film industry. In-depth interviews with representatives of the film industry, and secondary sources, such as legislation, reports and literature, are analysed and examined.

Keywords: Film Value Chain, VoD, digital platforms, COVID-19 pandemic, cinema theater

Received: 01.03.2021 - Accepted: 15.11.2021

http://ilefdergisi.ankara.edu.tr

ilef dergisi - ( 2021 - Özel Sayı - güz/autumn: 99-126

Research Article DOI: 10.24955/ilef.1037981 


\section{Giriș $^{1}$}

COVID-19 bir sağlık sorunu olarak başlamış, kapsamı ve süresi bağlamında her türlü alanı etkileyen ve krize dönüştüren bir pandemi olmuştur. UNESCO (2020) COVID-19 pandemisini kriz olarak değerlendirmektedir. COVID-19 pandemisi ve yarattığı kriz, kültürel ve yaratıcı endüstriler üzerinde yıkıcı bir etkiye sahip olmuştur. Dünyada pandemi ve sinemada kriz ilişkisini tarihsel olarak inceleyebileceğimiz önemli bir olay 1918 İspanyol gribidir. COVID-19 pandemisinin ortaya çıkmasıyla birlikte özellikle Amerika Birleşik Devletleri'nde, İspanyol gribi sonrası sinema endüstrisinin tarihsel olarak nasıl etkilendiği ve şekillendiği tartışılmaya başlamıştır. Buradan hareketle de bugün COVID-19 sonrası sinema endüstrisinin nasıl şekilleneceği üzerine projeksiyonlar yapılmaktadır (Brody 2020). İspanyol gribi, küçük işletmecilerin, yapımcıların ve dağıtımcıların ortadan kalkmasına neden olarak Hollywood sisteminin oluşmasını sağlamıştır (Brody 2020; Andreeva 2020;

1 Bu makale "COVID-19 Pandemisi ve Sinema Sektöründe Kriz" başlıklı 120K625 numaralı TÜBITTAK-SOBAG 1001 COVID-19 ve TOPLUM konulu projeden elde edilmiştir. Yazarlar araştırma desteği için TÜBİTAK'a teşekkür ederler. Bu makale ayrıca 26-28 Ekim 2020 tarihleri arasında düzenlenen 2. Uluslararası Dijital Çağda İletişim Sempozyumu'nda sunulan bildirinin geliştirilmiş bir halidir. 
Meares 2020). COVID-19 pandemisi de İspanyol gribine benzer bir biçimde sektörün işleyişinde değişimlere neden olarak yapım-dağıtım-gösterim aksında önemli bir kırılmayı ve yeni bir yapılanmayı getirmektedir. Bir diğer deyişle COVID-19 pandemisi, sinema endüstrisinde "yeni bir dikey yapılanmayı ve işleyişi doğurmakta, sinema salonlarının geleceğini tartışmaya açmaktadır" (Yılmaz 2020). ${ }^{2}$ Dijital platformlar bağlamında sinema endüstrisindeki bu değişimler, en çok sinema salonlarını etkilemektedir. Çünkü pandemiyle birlikte başlayan kapanma sürecinde, stüdyolar filmlerini sinema salonlarında gösterime sokmadan dijital platformlara yönelmektedirler. ABD'de COVID-19 pandemisinin sinema endüstrisinde yarattığı krizi anlamak için şu çarpıcı rakamlar yeterli olacaktır: 120.000'i Hollywood'da olmak üzere toplam 170.000 kişinin COVID-19'a bağlı olarak sinema endüstrisinde işsiz kaldığı ileri sürülmektedir (Pulver 2020). ABD'de 2020 yılının gişe gelirlerinin 2019'a göre \%80 düştüğü belirtilmektedir (Rubin 2021). Türkiye' de 2020 yılında 32 hafta açık kalan sinema salonlarının gişe kaybı \%65 civarındadır (Yavuz 2020a). COVID-19 pandemisi ile sinema salonlarının kapanması ve yaşanan kriz, insanların evlerinde karantinaya alınması, dijital platformlara yönelimi artırmıştır. Burada sektör açısından bir açmaz vardır ve çelişkili bir durum ortaya çıkmaktadır. Evde kalan seyircinin seyir merakı ve boş vaktini değerlendirmek için "içerik" lere ${ }^{3}$ (film, dizi) ihtiyacı vardır; ancak endüstri için önemli itki olabilecek bu durum COVID-19 pandemisinden dolayı üretime dönüşememektedir. Bu durumda gösterimi ertelenen filmler ve arşivdeki filmler için dijital platformlar önemli bir adres olarak karşımıza çıkmaktadır. Pandemi nedeniyle sosyal etkileşimin azalmasına ek olarak geleceğe yönelik ekonomik kaygıların artması, seyircileri tasarruf etmeye yönlendirmektedir ve sinema sektöründeki toparlanmanın diğer sektörlere göre daha yavaş gerçekleşeceği öngörülmektedir. Sinema sektöründe azalan talep Netflix gibi dijital platformlara kaymıştır. Örneğin Netflix'e pandeminin başında (2020 ilk çeyreğinde) 16 milyon yeni abone eklenmiştir (Swartz 2020). Avrupa'da 22 Haziran'da sinema salonlarının yeniden açılmasından bu yana Fransa'da

2 Bu konuya dair ayrıntıları Sineblog'daki söyleşide bulabilirsiniz (Yılmaz, 2020).

3 İçerik sözcüğünün kullanımı sinemacılardan eleştiri almaktadır. Scorsese (2021), Fellini üzerine yazdığı makalede, içerik sözcüğünün biçim-içerik ilişkisinden filmleri de içeren video formatındaki her şeyi kapsayan ticari bir terim haline gelmesini ve dijital platformların algoritmalarla seyircinin önüne benzer filmleri çıkartmasını eleştirmektedir. Bu durumu sinema sanatı ve tarihi hakkında hiçbir şey bilmeyen medya yöneticilerinin her şeye iş diye bakmalarının ve dijital platformların sinemaya gitme deneyimini bozmalarını bir sonucu olarak görür ve bu sinema sanatına ne yapar diye sorar. Buna karşın Cem Say “Netflix algoritmasız olabilir mi, tüm olayı bu değil mi?” demektedir (Kaynak, 2019). Bu konuda sinemacılar ile bilişimcilerin farklı düşündüğü gözlenmektedir. 
ağustos ayı sonuna kadar sinema salonuna giden seyirci sayısında geçen yıla göre \%67, Almanya ve İspanya' da \%80, İtalya'da \%86 ve Büyük Britanya'da \%90 oranında düşüş gözlenmiştir (Vulser 2020). Türkiye' de 1 Temmuz 2020 tarihinde açılan sinema salonları 17 Kasım 2020 tarihinde kapatılana kadar ortalama $\% 1$ doluluk oranı ile çalışmıştır. ${ }^{4}$ COVID-19 pandemisinin sinema endüstrisinde yarattığı kriz, sinema salonuna giden seyirci bağlamında derinleşerek devam etmektedir.

Bir diğer önemli unsur sinema endüstrisinin yapısal olarak değişimi ile ilgilidir. Sinemada üretim tarzı konvansiyonelden (peliküle dayalı üretim tarzı) dijital üretim tarzına evrilmiştir ve süreç devam etmektedir. Teknolojik değişimler kültürel tüketim pratiklerini değiştirmektedir. Dijitalleşme ile birlikte değişen ve gelişen seyir pratiklerini de bu bağlamda okumak gerekmektedir. Sinemada dijitalleşme ve bunun getirdiği yapısal değişimler (örneğin seyir kültüründeki yenilikler, dijital platformlar gibi), sinemanın kendi iç dinamiklerinin yanında küresel kapitalizmin dijital kapitalizme dönüşümü ile ilgilidir. COVID-19 pandemisi değişimi hızlandıran bir katalizör işlevi görmüştür. Sinema endüstrisinin tarihsel gelişiminde bir dizi teknolojik icadın önemi büyüktür: Kare hızının standartlaşması, sesin gelişi, renkli film, geniş perde, cinemascope, stereo, 3D, dolby surround, dijitalleşme örneklerinde görüldüğü gibi. Sinemanın konvansiyonel üretim tarzından dijital üretim tarzına geçişi sırasında stüdyoların çeşitli VoD biçimlerine adapte olmalarında sorunlar vardır. Bu süreçte ABD'de ev sinema satışları (DVD, BluRay) değer zincirindeki önemini korumaktadır. Dijital dönüşüm 2013 yılında dağıtım ve gösterimin DCP (Digital Cinema Package, Dijital Sinema Paketi) üzerinden gerçekleşmesi ile büyük bir sıçrama yaşamıştır (Tryon 2013). Bu çok katmanlı etki, sinema endüstrisinin geleneksel iş ekosisteminin ve değer zincirinin yeniden yapılandırılmasına yol açmaktadır (Salvador, Simon ve Benghazi 2019, 13-14). Değer zincirindeki değişim, pelikülün yapım ve gösterim bağlamında ortadan kalkması sırasında gündeme gelen sinemanın ölümü tartışmalarını hatırlatır (Cherchi Ushai 2001; Belton 2002; Gaudreault ve Marion 2015). Her büyük değişim, eskinin öldüğünü, yeninin doğduğunu ifade eder. Oysa sinemada dijitalleşmeyi bir kopuş değil, bir evrim olarak değerlendirmek gerekir (Erkılıç 2017). Pandemi ile sinema endüstrisinin kabul gören işleyiş ve iş akış1nın keskin bir biçimde değişmesi sürecinde Türkiye'nin kendi pratiklerinden yola çıkarak buna nasıl cevap vereceği önemli bir sorunsal olarak karşımızda $\bullet$

421 Eylül 2020 tarihinde K4 ile yapılan derinlemesine görüşme. Daha sonra sinema salonlarının kapanma tarihi düzenli olarak uzatılmış ve salonlar 1 Temmuz 2021 tarihine kadar kapalı kalmıştır. 
durmaktadır. Buna ilişkin öngörüler mevcut yasal çerçevedeki değişiklikler ile şekillenebilmektedir. Ancak gündelik yaşamdaki ve tüketim alışkanlıklarındaki değişikliklerin oluşturacağı dinamikleri ve bu dinamiklerle zaten gelişimini tamamlamamış, endüstrileşememiş Türk sinema sektörünü ne yönde etkileyeceği ayrıca çalışılması gereken bir alan olarak durmaktadır.

Bu makale, Türkiye'de COVID-19 pandemisinin sinema sektörüne etkilerini dijital platformların gelişmesi bağlamında ele almakta ve buna bağlı olarak değer zincirindeki değişime odaklanmaktadır. Makalede, bağlamsal yaklaşımla sinema değer zinciri içinde gün geçtikçe yükseliş eğrisi gösteren dijital platformlar Türkiye özelinde incelenmektedir. Küresel sinema endüstrisinde ve Türkiye' deki gelişmeler ile yasal düzenlemeler makalenin çalışma çerçevesini çizmektedir. Ayrıca Comolli ve Narboni'nin $(1989,59)$ “Her film ekonomik sistemin bir unsuru (...) bir yanıyla verili ekonomik ilişkiler içinde üretilen kendine özgü bir üründür" ifadesi ile Brecht'in $(1974,50)$ "Bir filmin sanat değeri en yüksek olanının bile, bir meta olduğunda herkes anlaşıyor" saptaması sinema değer zinciri okuması için çıkış noktamızı oluşturmaktadır. Makale üç bölümden oluşmaktadır. Birinci bölümde sinema değer zinciri kavramı genel olarak ele alınmaktadır. İkinci bölümde, dünyada ve özellikle Hollywood'da dijital platformlar ve değer zinciri ilişkisi genel olarak değerlendirilmektedir. Üçüncü bölümde dijital platformların Türk sinema sektörüne etkileri tartışılmaktadır: COVID-19 pandemisi ve sinema salonlarının kapanması gibi görünür kritik sorunlar ile mevzuata dair görünmeyen yapısal endişeler incelenmektedir. Sonuç bölümünde ise dijital platformların yıllık gelirinin $\% 2-3$ 'ünün sinema salonlarına destek olmak şartıyla sinema fonuna aktarımı önerilmektedir. Metodoloji, derinlemesine görüşmelerden elde edilen nitel saha verilerine ve ikincil kaynakların inceleme ve analizine dayanmaktadır. Dijital platformlar ve sinema salonları arasındaki ilişki, bağlamsal yaklaşımla ${ }^{5}$ (Turner 1999, 153) ulusal bir film endüstrisinin kültürel, politik, kurumsal, endüstriyel belirleyicilerinden biri olarak sinema değer zinciri içinde analiz edilmektedir. COVID-19 pandemisinin sinema sektörüne etkisi ve $\cdots$

5 Turner (1999, 153-154) bağlamsal yaklaşımların çoğunlukla ulusal bir sinema endüstrisinin kültürel, politik, kurumsal, endüstriyel belirleyicilerini analiz etme eğiliminde oldukları$\mathrm{n} ı$ belirtir. Bu çalışmalar temsil çalışmasından ziyade kültürel üretim süreci ile ilgilenirler. Bağlamsal yaklaşım, kültür politikasının, hükümet müdahalesinin, sansürün, teknolojilerin, üretim-dağıtım-gösterim zinciri içindeki mülkiyet ilişkilerinin, sinema endüstrisindeki ticari uygulamaların, kamu kurumlarının, sinema endüstrisinin küresel yönlerinin ve sinema endüstrisini etkileyen diğer birçok faktörün işlevini inceler. Turner, bu çerçevede $\mathrm{ABD}^{\prime}$ den Kristin Thompson ve Douglas Gomery, İngiltere'den John Ellis ve Charles Barr, Avustralya'dan ise John Tulloch ve Tom O’Regan'ın çalışmalarını örneklendirir. 
dijital platformların yükselişi ile birlikte değer zincirindeki değişim, 52 sektör temsilcisi ile yapılan derinlemesine görüşmelerden elde edilen nitel veriler kullanılarak değerlendirilmiştir. Derinlemesine görüşme yapılan katılımcılar metin içinde, K1-K52 arasında kodlanmıştır.

\section{Sinema Değer Zinciri}

İnternet ve dijital pratiklerin yaygınlaşması değer zincirinde tartışmaları da doğurmuştur (Ulin, 2010; Erkılıç ve Toprak 2012, Pardo 2014). Sinema değer zinciri son on yılda küresel sinema endüstrisinde ortaya çıan en önemli ticari analitik kavram olarak tanımlanmaktadır. Sinema endüstrisi açısından bu değer zinciri film yapım sürecine dahil olan tüm tarafları kapsamalıdır. Sinema değer zinciri, tamamı film yapım ve dağıtım sürecinin farklı unsurları üzerinde çalışan bağlantılı şirketler ve bireylerden oluşan bir yapıdadır. Değer zinciri yaklaşımı, film üretim sürecinin başlangıcından seyircinin izlemesine kadar bir filmin tüm sürecine bakmakla ilgilidir (Eliashberg vd. 2006; Davies ve Wistreich 2007, Vang ve Chaminade 2007; Küng 2008). Tarihsel olarak film dağıtımı, film değer zincirindeki ana risk alıcı olmuştur (Finney 2010, 14). Sürecin birbiriyle bağlantılı yatay unsurları tipik olarak aşağıdaki aşamaları takip eder:

\section{Șekil 1. Sinema değer zinciri}
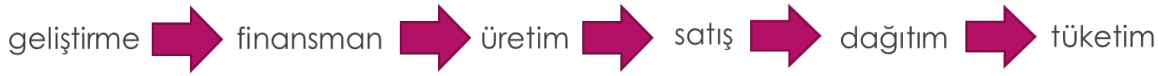

Bu unsurların her biri, bir film projesini ilerletmek için dikey olarak bağlantılı bir dizi aktiviteye sahiptir. Finney $(2010,6)$ sistemi "parçalanmış bir model" olarak adlandırır. Geleneksel film dağıtımı iş modeli, geliri en üst düzeye çıkarmak için bir filmin fikri mülkiyet haklarının tekrar tekrar ticari olarak kullanılmasını sağlamak üzere, belirli pazar bölgeleri içinde özel zaman dilimleri olan pencerelerin yaşam döngüsü etrafında oluşturulmuştur. Pencereler arasında rekabet olmamasını sağlamak için belirlenen zaman dilimlerine engelleme süreleri denir (Ulin 2010, 36). Dağıtım için film değer zinciri, tipik olarak sinema salonu gösterimi için özel bir pencere ile başlayan bir dizi dikey bağlantılı faaliyetle birbirine bağlıdır ve sinema endüstrisinde gösterim mecraları (sinema salonu, televizyon, dijital platform gibi) pencere olarak ifade edilir. Engelleme süreleri ABD'de yasa ile değil endüstri bileşenlerinin uylaşımlarına göre belirlenmektedir. ${ }^{6}$

\section{$\bullet \bullet$}

6 Erteleme süreleri ülkeden ülkeye farklılık göstermektedir. ABD' de sektörel uylaşım belirleyici olurken, Fransa ve Türkiye'de yasal düzenlemeler belirleyici olmaktadır. 
Gösterim pencereleri içinde \%40-50 oranında birinci sırada sinema salonları, ikinci sırada televizyon satışları, üçüncü sırada ev sineması, dördüncü sırada ürün satışları yer almaktadır. Bu tablo gelişen dijital teknolojiler sonucu vizyon pencereleri ve engelleme süreleri "ev video penceresi" (yani DVD/Blu-ray) için yaklaşık 17 hafta, izleme başına ödeme ve talep üzerine video (VoD) için 6 ay, Pay-TV aboneliği için 12 ay ve ücretsiz televizyon yayını için 24 ay şeklindedir (Ulin 2010, 36). ABD'de stüdyoların değer zinciri içinde ev sineması önemli bir kalem tutmakta ve dijital gösterimlerin yasal koruması noktasında endişeleri bulunmaktadır. Buna karşın pandemi ile birlikte eve kapanma ve sinema salonlarının uzun süre kapalı olması, dijital platform seçeneğini ön plana çıkartmış ve stüdyolar ile sinema salonu işletmecileri arasında pencere ve erteleme sürelerine ilişkin uzlaşı bozulmuştur. Hollywood'da stüdyoların dijital platform atağı bu konudaki değişimin hızını göstermesi açısından anlamlıdır. Universal, Trolls World Tour (Schwartzel 2020) ile King of Staten Island'1, Warner Brothers ise Scoob! (Vanacker 2020), Disney+ Artemis Fowl, Onward, Mulan filmlerini sinema salonu gösterimlerini beklemeksizin, dijital platformlarda gösterime sokmuşlardır (Vary \& Rubin, 2020). Trolls World Tour'un ABD' de dijital olarak kiralanabildiği üç hafta içerisinde yaklaşı 100 milyon ABD doları hasılat elde ettiği ortaya koyulmaktadır. PVoD modelinde elde edilen hasılatın \%80'ine sahip olan Universal, böylelikle sadece 19 günde yaklaşık 80 milyon ABD doları elde etmiştir. Sinema salonlarında elde edilen hasılat, salonlarla yapılan anlaşmalara göre değişiklik gösterse de, \%50 civarı bir payın sahibi olan Universal, 2016 yılında gösterime giren ilk film Trolls' un ABD'de toplam 153,7 milyon ABD doları hasılat elde etmesi sonucunda yine yaklaşık 80 milyon ABD doları kazanmıştır (Kerr ve Cyba 2020). Pandemiden dolayı 2020 sinema salonu gösterimleri iptal edilen No Time To Die, Black Widow, Wonder Woman 1984, West Side Story 2021 yılına; Avatar 2 ve The Batman adlı yapımların gösterimleri 2022 yılına ertelenmiştir. Bu filmleri almak için dijital platformlar arasında büyük savaş devam etmektedir. Bu süreçte WarnerMedia'nın (WB) açıklamaları işin boyutunu değiştirecek düzeydedir. WarnerMedia (WB) Aralık ayının başında 2021 yılında sinema salonu gösterimleri (theatrical window) ile aynı anda dijital platformda da filmlerini abonelerine (ABD'deki HBO Max aboneleri için) ücretsiz olarak göstereceğini duyurmuştur (Kovach 2020). Bu pencereler arası gösterim mesafesini yok ettiği gibi sinema salonu gelirlerinin düşeceği anlamına gelmektedir. Bu açıklama ABD'de, COVID-19 pandemisi nedeniyle sinema salonları kapanma sorunuyla boğuşurken, büyük bir film stüdyosundan gelen cesur bir hareket olarak değerlendirilmiştir. Bu durum, dijital platform üyesi olan 
bir seyircinin, sinema salonuna gitmeksizin evinizde WB ait Dune, The Matrix 4, The Suicide Squad, Wonder Woman 1984, Christmas Day gibi sinema salonu gişe beklentisi yüksek olan filmleri izleyebileceği anlamına gelir. WB'nin bu kararı sinema salonu zincirlerinden ve yönetmenlerden tepki almıştır. Örneğin Dune filminin yönetmeni Denis Villeneuve (2020) WB'yi grubun telekomünikasyon bölümünü kurtarmak için sinemayı kullandığı için eleştirmiş ve tepkisini "Yaşasın salonlardaki sinema" sözleriyle dile getirmiştir.

Değer zincirindeki ekonomik denge, potansiyel olarak üst düzey hizmetler (örneğin Netflix), telekomünikasyon şirketleri ve kablo operatörleri gibi altyapıları kontrol eden aktörlere doğru kaymaktadır (Salvador, Simon ve Benghazi 2019, 5). Bu süreçte dijital dönüşüm sinema ve televizyon endüstrisinde ciddi değişimlere neden olmakta, medya ekolojisinin iş modelini dönüştürmektedir. Finney (2010) bu dönüşümü Yeni Medya İş Modeli veya Business 2.0 (İş Modeli 2.0) olarak adlandırır.7 İş modeli 2.0〉ın temeli internet, çevrimiçi platformdur (Finney 2015) ve bu modelde yeni değer zinciri ise şöyle formüle edilmektedir (Finney 2014, 6).

\section{Sekil 2. Yeni Sinema Değer Zinciri}

\section{Yapımci $\rightarrow$ Koleksiyoncu $\rightarrow$ Seyirci}

Yeni değer zinciri, sinema endüstrisindeki yapımcı (producer), koleksiyoncular (aggregators) ve seyirci/tüketici (consumer) gibi ana katılımcılardan oluşmaktadır. Koleksiyoncular, bu modelde Netflix, Amazon Prime, Apple gibi dijital platformlardır.

$\mathrm{Bu}$ çerçevede Jenkis'in yöndeşme (convergence) kavramına başvurmakta fayda vardır. Jenkins'in (2006) farklı medyanın iç içe olması ve tek bir medyadan birden çok medyaya ulaşılması olarak ifade ettiği yöndeşme, konumuz bağlamında dijital platformlar olarak karşımıza çıkmaktadır. Böylece yayıncılık (broadcasting), telekomünikasyon (iletişim) ve bilgi işlem teknolojileri (bilgisayar ve internet) ekosistem olarak dijital platformlarda bütünleşmektedir. Murdock (2000, 35-37) sinema endüstrisi açısından yöndeşmeyi üç başlık altında ele almaktadır. Kültürel formların yöndeşmesi, bütün kültürel içeriklerin tek bir araçta bir arada olması ve kullanıcının bu içerikler arasında seçim yaparak aktif konuma geçmesi durumudur. İletişim sistemlerinin -..

7 İş Modeli 2.0'ın farklı uygulamalarına ve değer zincirinin genel değerlendirmesi için bkz. Vitkauskaitè (2020). Dijital dönüşümün belgesel sinemaya yarattı̆̆ olanaklar için bkz. (Erkılıç ve Toprak, 2012). 
yöndeşmesi, her tür enformasyonun her grup müşteriye taşınabildiği açık sistemlere dikkat çekmektedir. Şirket sahipliklerinin yöndeşmesi ise değişik medya sektörleri arasındaki sınırların ortadan kalkması ve ayrı olan şirket çıkarlarının yakınlaşması anlamına gelmektedir. Meikle ve Young $(2012,35)$ ise bu durumu medya bütünleşmesi ve genişleme süreçlerinin küresel şirketler aracılığıyla daha büyük, daha entegre, daha ağa bağlı hale gelmesi ve medya şirketlerinin teknolojik yöndeşme potansiyelini benimsemesiyle hızlı bir biçimde uyarlama yolları araması olarak tanımlamaktadır. Yazılım, donanım ve düşüncenin birlikte örgütlendiği bu yapılanma Google, Amazon, Apple veya diğer internet servis sağlayıcıları gibi teknolojileri destekleyen ve desteklenen teknolojik aracılar ve ekonomik aktörler haline getirmiştir. Bu süreç, sinema endüstrisinin film yapımına odaklı "proje bazlı üretim"den teknoloji şirketleri aracılığıyla faaliyet gösteren, teknolojik birikim ve endüstriyel bir ekosistemde örgütlenen firmalar aracılığıyla “iş bazlı üretim”e doğru yönelmesini sağlamıştır (Salvador, Simon ve Benghozi 2019, 13). Bu çerçevede sinema endüstrisi, dijital bir ekosistem olarak değerlendirilmektedir (Nilsen ve Smistad 2012) ve "bu yeni oyuncular, geçmiş doğrusal değer zincirlerinin aksine, çok sayıda teknik aracı belirli değer ağlarında sergiledikleri için değer zinciri büyük ölçüde değişmekte ve giderek daha karmaşık bir hale" (Salvador, Simon ve Benghozi 2019, 21) gelmektedir.

\section{Dijital Platformlar ${ }^{8}$}

Dijital platformların yükselişi, ekonomik ilerlemenin ve teknolojik yeniliğin itici gücü olarak görülmektedir (van Dick, Poell ve Wall 2018). Talep Üzerine Video (VoD/Video on Demand), genellikle tüketicinin içeriği internet erişimi ile ne zaman (her zaman) ve nerede (her yerden) izleyeceğine seçme olanağ1 verir. İnternet kullanımının temel bir özellik olduğu OTT (Over the Top) video servisleri içeriği sunma ve gelir elde edilme biçimlerine göre dört grupta toplanir.

$\bullet \bullet$

8 İsteğe bağlı video (Video on demand/VoD) olarak genel kabul gören streaming platformlar olarak da ifade edilen dijital platformlar teknik olarak OTT (Over the Top/Her şeyin üzerinde) olarak ifade edilmektedir. OTT, içeriği doğrudan internet üzerinden dağıtan, video içerik sağlayıcılarının, streaming hizmetinin genel adıdır. Makalede, yaygın kullanım nedeniyle dijital platform tercih edilmiştir. Dijital platformlar, fiziksel ürünleri tamamen dijitale dönüştürmeleri, salon gösterimleri sırasında aynı anda film yayınlamaya başlamaları ve böylece piyasa işleyişini kesintiye uğratarak yeni bir piyasa oluşturmaları nedeniyle Digital Disruptive Intermediaries (Dijital Yıkıcı Aracılar) içinde de değerlendirilmiştir (Raimer vd 2015). 
SVoD (İstek üzerine abonelik videosu- Subscription Video on Demand), abone ol, seç izle modeli: Kullanıcıların aylık sabit bir oranda istedikleri kadar içerik tüketmelerine olanak tanıyan sistemlerdir. Sky, Netflix, Amazon Prime Video, Hulu, Apple, HBO ve Disney+, Blu TV, MUBİ gibi platformlar buna örnektir.

TVoD (isteğe bağlı işlemsel video- Transactional Video on Demand): Bu modelde kullanıcılar izledikleri içerik başına bir ücret öderler. Kirala izle ya da satın al izle modelidir. Ömür boyu satın al Digitürk, Blu-TV / Başka sinema uygulaması kirala izle buna örnektir. TVoD hizmetlerine örnek olarak ise Apple'ın iTunes, Sky Box Office ve Amazon'un video mağazası, Vudu verilebilir.

AVoD (Reklama bağlı video- Advertising-based Video on Demand): Tüketiciler için ücretsizdir. Ancak, televizyon yayını gibi, tüketicilerin de reklamları izlemesi gerekir. DailyMotion, YouTube, Puhu TV örneklendirilebilir.

PVoD (Premium Video on Demand): Doğrudan video akışında yayınlanan, sinema salon gösterimi tamamen atlanan veya sinema salonlarına ç1kışlarını kısa kesen filmlerdir. İzleyiciler bu filmleri platformlardan kiralayıp evde izleyebilirler.

ABD'de COVID-19 pandemi krizi ile birlikte pencereler ve erteleme süreleri konusunda stüdyolar ile sinema salon işletmecileri arasındaki en büyük kırılma PVoD'de gerçekleşmiştir. Universal ve Focus, bu süreyi 17 güne çekmiş ve en büyük işletmeci grubu olan AMC ile anlaşmaya varmıştır (D'Alessandro 2020a). Diğer büyük işletmeci zincirleri Cineworld ve Cinemark, bu anlaşmayı "agresif kısaltılmış sinema salonu penceresi" olarak değerlendirerek filmin değer zinciri için olumsuz bir etkiye neden olabileceğini belirtmişlerdir (D'Alessandro ve Tartaglione 2020; D'Alessandro 2020b). 2021 yılındaki son gelişme Paramount+'dan gelmiştir. Paramount+, pencereler arası erteleme süresini 45 gün olarak belirlemiştir. Bu yaklaşım sinema işletmecileri tarafından olumlu karşılanmıştır. Böylece A Quiet Place Part II ve Mission Impossible 7 sinema salonlarında gösterime girdikten 45 gün sonra Paramount+'da yayınlanmış olacaktır (D'Alessandro 2021). Daha önce de ifade edildiği gibi ABD'de stüdyolar ile sinema işletmecileri arasındaki pencere ve erteleme sürelerine dair uylaşımlara dayanan yapı kırılmış ve COVID-19 pandemisi ile birlikte dijital platformlar üzerinden yeniden yapılanmaya dönüşmüştür.

Dijital platformlar içinde ön plana çıkan Netflix'e daha yakından bakmak faydalı olacaktır. Netflix, ABD merkezli isteğe bağlı internet akış medyası sağ- 
layıcısıdır. 1997 yılında, endüstri standardı olan "film başına öde" ücretlerinin yerine, aylık abonelik getiren bir DVD kiralama modeliyle başlayan Netflix, 2007 ' de internet üzerinden isteğe bağlı video kiralama hizmetini başlatır. Netflix 2016 yılının sonlarına doğru tüm AB ülkeleri ve Türkiye dâhil birçok ülkede yayın yapmaya başlamıştır. Amazon on Prime, 2006 yılında Amerika'da "Amazon Unbox" olarak başlamıştır. Ancak 2016 yılına kadar dünya çapında lanse edilmemiştir. Amazon 2012 yılında Netflix'e rakip olmak için ödemeli TV kanalı Epix ile anlaşarak kataloğundaki filmlerin sayısını arttırmıştır.

Küresel bir aktör olarak hem dağıtımda hem de yapım grubunda faaliyet gösteren dijital platformlar, küresel sinema endüstrisi için yeni bir ekonomik güç olarak görülmektedirler (Lobato 2019). Platformların yaygınlaşmasından etkilenen bir başka yapılanma da film festivalleri olmuştur. Festivaller COVID-19 pandemisi öncesi özel gösterimleri VoD platformları üzerinden yaparak bu anlamdaki etkileşimi başlatmışlardır. Revelation Perth Uluslararası Film Festivali, Aralık 2015'te talep üzerine REV on Demand hizmetini başlatmış; Melbourne Uluslararası Film Festivali ise yine aynı yıl VoD'de "MIFF ilk 10 " retrospektifinin küratörlüğünü yapmıştır. Bu uygulamalar, dijital teknolojinin yükselişinin festival operasyonunda yeni bir dönemin habercisi olarak yorumlanmıştır (Stevens 2016, 204). COVID-19 pandemisi festivalleri ya erteleme ya da iptale götürürken, gerçekleştirilebilen festivaller de tamamen çevrimiçi veya karma bir yöntemle hem yerinde fiziksel hem de çevrimiçi etkinlikler gerçekleştirmek zorunda kalmışlardır (Erkılıç, Duruel Erkılıç ve Değirmen 2020). COVID-19 salgını sonrası seyirciyle bir araya gelmede alternatif yollar arayan film festivalleri, ortak olarak We Are One: A Global Film Festival projesiyle seyirciyle buluşma yoluna gitmişlerdir. 29 Mayıs-7 Haziran 2020 tarihleri arasında YouTube üzerinden gerçekleştirilen online film festivalinde, reklamsız ve ücretsiz bir şekilde uzun metrajdan kısa metraja, belgeselden panele çeşitli içerikler erişime açılmıştır (Spangler 2020). 10-21 Nisan 2020 tarihinde yapılması planlanan 39. İstanbul Film Festivali önce online bir seçki, sonra yarışma filmlerinin sinema salonlarında gösterimini içeren karma bir program uygulamıştır. COVID-19 pandemisi online festivalleri, festival döngüsünün merkezine taşımaktadır. Festivale gitmek bir "tık" uzaklıktaki bir deneyime dönüşürken festival kartı yerine kişisel bir kod, programlara belli süreler içinde erişim (Strauven 2020) online festivallerin yeni ritüelini oluşturmaktadır. ${ }^{9}$

$\bullet \bullet$

9 COVID-19 pandemisi ve film festivalleri ilişkisi yazarların yayım aşamasında olan COVID-19 Pandemisi ve Film Festivalleri: Karma ya da Çevrimiçi adlı makalelerinde ayrıntılı olarak işlenmektedir. 
Hızla artan geniş bant sayesinde daha uygulanabilir hale gelmesine rağmen, platform hareketliliğinin yaygın kabul görmesi, yalnızca teknolojik faktörlerin değil, aynı zamanda kültürel değişikliklerin de sonucudur (Troyn 2013, 19). Bu kültürel değişim pandemi süresince hızlanmıştır. Salonların kapanması, eve kapanma, salonların açıldığında yeni içerik sıkıntısı ve salgının devam etmesi dijital platformlara olan ilgiyi artırmış; daha ucuz ve daha kolay yoldan içeriğe erişim olanağı getirmiştir. ${ }^{10}$ Pandemi bu süreçte katalizör işlevi görerek seyir pratiğindeki kültürel değişimi hızlandırmıştır.

\section{Yasal Düzenlemeler}

Cunat'a (2019) göre Avrupa' daki küresel dijital platformların yükselişi, Avrupa Birliği'nde $(\mathrm{AB})$ sinemanın düşüş gösteren bir eğri çizmeye başlamasına ve yapımın ana destekçileri olan kamu yayıncılarının harcamalarının azalmasına paralel gerçekleşmiştir. AB ülkeleri dijital platformlardaki yerli yapım sayısını artırmaya başlamış ve ulusal sinema endüstrisine katkı açısından da gelirlerinden pay almak için yasal düzenlemelere başvurmuştur. AB' de 2018 yılında kabul edilen Görsel-İşitsel Medya Hizmetleri Direktifi (Audiovisual Media Services Directive - AVMSD), üye ülkelere yabancı dijital platform hizmetlerine mali yükümlülükler getirme izni vermektedir (Leiva ve Albornoz 2020). 2020 yılının başında Fransa, Almanya, Belçika ve İtalya düzenlemeler yapmış; Fransa'da yapılan düzenlemeyle dijital platform gelirlerinin $\% 2$ 'si sinema fonuna aktarılmıştır (Kostovska, Raats ve Donders 2020, 1-2). ${ }^{11}$ AB ülkeleri tarafından 2018 yılında Görsel-İşitsel Medya Hizmetleri Direktifi'nde (AVMSD) yapılan değişiklikle VoD servis sağlayıcılarının kataloglarında, Avrupa ülkelerindeki üretimlerin yer alması sağlanmıştır (Leiva ve Albornoz 2020).

10 Deloitte araştırma şirketinin ABD'de Mayıs 2020'de yaptığı dijital medya trendleri anketi pandemide gençlerin ve çocuklu ailelerin dijital platformlara yöneldiğini göstermektedir. ABD tüketicilerinin \%22'sinin- Gen X'in \%24'ü ve Y Kuşağı'nın \%36'sı dahil- PVoD arac1lığıyla yeni bir sürümü izlemek için para ödediğini ortaya çıkarmıştır. Şaşırtıcı olmayan bir şekilde evde çocuklu tüketiciler için rakam önemli ölçüde artmıştır. Aslında, çocuklu Y kuşağının \%51'i en az bir PVoD filmi kiraladıklarını bildirmiştir. Çocuklu Y kuşağı ve ücretli bir video akışı hizmeti için bu sayı \%56'ya çıkmıştır (Wescot 2020).

112018 itibariyle önlemler seti Centre National du Cinéma'ya (CNC) yıllık ciroları üzerinden $\% 2$ vergi ödemek zorunda olan yerel olmayan VoD hizmetlerini içerecek şekilde genişletilmiştir. CNC, 2018' de video ve VoD hizmetlerinden 25,7 milyon Euro harç toplamış ve bu bir önceki yıla göre \%58 artış göstermiştir (Besson ve Danard'dan aktaran Kostovska, Raats ve Donders 2020). 


\section{Sinema Salonlarının Durumu}

Christopher Nolan'ın Tenet (2020) filminin pandeminin seyrine rağmen sinema salonu gösterimini gerçekleştirmesi, sinema salonları açısından bir umut olarak görülmüştür. Küresel olarak 350 milyon dolar gelir elde eden film tartışmalara neden olmuştur. Tartışmanın bir ayağı pandemi koşullarına rağmen Tenet' in gişesini olumlu bulurken (Yavuz 2020b), karşı argümanlar ironik bir şekilde Tenet'in pandemide sinemayı öldürdüğünü iddia etmektedirler (Lodge 2020). Pandeminin seyri ve Tenet'in umulanın altındaki gişesi stüdyoların dijital platformlara yönelmesinde ve erteleme sürelerini kısaltmalarında etkili olmuştur.

Sinema salonlarında mekânsal arayış da bu dönem için önemlidir. Ōma Cinema (Vertical Immersive Experience - Dikey sarmalayan deneyim), Star Wars filminin senato mekânını anımsatan eski İtalyan opera binalarından esinlendiği belirtilen mimari yapısı ile farklı bir sinema salonu mekânı tasarımı oluşturmaktadır. Geleneksel salon yapılanmasının yatay tasarımına karşılık dikeyde altışar koltuklu üç sıradan oluşan bölmelere ayrılmış özel oturma gruplarını (büyük loca olarak da ifade edilebilir) içermektedir. 2021 yılı içinde Paris'te açlacak olan Ōma Cinema, pandemide özellikle sağlık ve hijyen açısından kapalı mekanlara gidemeyen sinema seyircileri için yeni bir fırsat olarak sunulmaktadır (Ballard 2020).

Bir diğer arayış sinema salonlarının bir $h u b^{\prime} a$, bir anlamda kültür merkezine dönüşmesidir. Özellikle Fransa'da sinema salonları gelir getirici kalemler yaratabilmek için sinema salonunda opera, canlı konser, spor karşılaşmaları gibi sinema dışı etkinlikler yayınlamaktadırlar (Gaudreault ve Marion 2020, 16-17). Sinema salonunun bir $h u b^{\prime}$ a dönüşmesi, sinema dışı gösterim ve etkinliklerle gelir elde etmesi ve böylece film göstermeye devam edebilmesi sağlanmaktadır. ${ }^{12}$

\section{Türkiye'de Dijital Platformların Seyri}

Türkiye'de 2016 yılında BluTV, PuHu TV, Netflix, 2020 yılında Amazon Prime yayına başlamışlardır. 2020 yılının sonunda Gain ve Exxen gibi iki yeni platform daha katılmıştır. Disney + gibi küresel platformların Türkiye pazarına

$\cdots$

12 Avrupa Komisyonu 2020 yılı çağrıları arasında "Cinemas as Innovation Hubs for Local Communities" (Yerel Topluluklar için İnovasyon Merkezleri Olarak Sinema Salonları) yer almıştır: https: / / ec.europa.eu / digital-single-market/en/news/ preparatory-actioncinemas-innovation-hubs-local-communities 
gireceği belirtilmektedir (K25). Türkiye sinema sektörü ise dijital platformlarla "pop-corn krizi" olarak tanımlanan 2019 yılı içinde tanışmıştır. Yapımcılar ile salon işletmecileri arasında bilet gelir paylaşımı üzerinden yaşanan tartışma ana akım yapımcıların film gösterimlerini ertelemeleri ile krize dönüşmüştür. Yeni sinema yasası (7163) ve mevzuat düzenlemeleri ile çözülen kriz sonrası ana akım filmler gösterime girmişlerdir (Erem 2019). Bu bağlamda Netflix- Organize İşler - Sazan Sarmalı (Erdoğan 2019) işbirliği sinema sektörü ve dijital platformlar arasındaki ilişkiyi başlatmıştır. Film, 1 Şubat 2019'da Türkiye' de sinema salonlarında gösterime girdikten iki hafta sonra 15 Şubat 2019'da Netflix'te yayınlanmıştır. Film sinema salonlarında gösterilirken eşzamanlı olarak dijital platformda yer almıştır. Bu karar sinema işletmecileri ve meslek örgütleri Sinema Salonu Yatırımcıları Derneği (SİSAY) tarafından sinemaya darbe olarak nitelendirilmiştir (O karar ortalığı karıştırdı 2019).

\section{BluTV- Bașka Sinema Örneği}

BluTV, 2016 yılında Doğan Medya Grubu'nun dijital platformu olarak kurulmuştur. Netflix'e rakip olmak amacıyla kurulan platform, film ve dizi içerikleriyle yayınlarına başlamıştır (Dikkol 2020). Dijital platform BluTV, pandemi döneminde sinemalar kapalıyken Başka Sinema ile işbirliği yapmıştır. Bu işbirliği sonucu BluTV pandemi döneminde kirala izle modeli ile gösterime girmemiş filmleri yayınlamıştır. Bu filmlerden elde gelirlerden bir kısmının da sinema salonlarına aktarılacağı belirtilmiştir. Dönemin SİSAY Başkanı İrfan Demirkol bu uygulamayı eleştirmiş ve filmlerin dijital platformlarda gösterim süresinin/erteleme süresinin yasada belirtilen 5-6 ay yerine 11-12 ay olması gerektiğini belirtmiştir (Boxoffice Türkiye 2020b). Başka Sinema- BluTV işbirliğinin beklenen ilgiyi görmemesinin nedenlerini K5 şöyle ifade etmektedir: "Pazar yeni gelişiyor, internet bağlantı hızı hala sorun, arthouse yapımlar için etkili bir mecra olabilir. Başka Sinema-BluTV uygulaması başarılı olamad. Seyircinin beklentisini karşılayacak bir program da yoktu." Pandeminin başlangıç zamanında sinema salonlarının kapanması ve filmler için dijital platform arayışı, K6 tarafından "Sinema BluTV ilişkisi sektöre zarar verir. Başka Sinema-BluTV işbirliği sinema salonu işletmecileri tarafından tepkiyle karşılandı" şeklinde yorumlanmıştır. Oysa Türkiye özelinde sinema filmlerinin dijital platform süreci daha başlangıç aşamasında olup, ekonomik olarak büyük bir oran tutmamaktadır. Başka Sinema'dan Ersan Çongar Türkiye'de pandemi öncesi dijital platform gelirlerinin yüksek olmadığına şu sözlerle dikkat çekmektedir: "Bir filmin gelirlerinin yarısından fazlası sinemadan elde ediliyor. Online gelirler dediğimiz pay ise yıllık gelir içinde yüzde 1 ya da 
2." (Yücel ve Köstepen 2020). Türkiye'de pandemi öncesi dijital platformların değer zinciri içindeki yerini göstermesi açısından oldukça önemli olan bu açıklama, pandemi sonrası dijital platformların potansiyelinin gelişimi açısından önemlidir. K5'in ifade ettiği gibi "Gelecekte dağıtımı hibrit olacak: hem sinema salonları hem de dijital platformlar aynı anda çalışacak."

Dijital platformların genişleme ve ekonomik büyüme potansiyelini Netflix üzerinden okumak mümkündür. 2021 Mart ayı sonunda net gelirinin 1.355 milyon dolar ve küresel ücretli üyelik sayısının 209.66 milyon olacağı tahmin edilmektedir (Dziadul 2021). 2020'nin ilk çeyreğinde 200 bin civarında yeni abone kazanan Netflix'in Türkiye' deki abone sayısı 1.7 milyonu geride bırakmıştır. Bu rakamın Türkiye'deki gelir yansıması ise 53 milyon dolar olarak açılanmıştır. CompariTech'in açıladığı rapora göre, ikinci çeyrek sonunda Türkiye' deki abone sayısının 1.9 milyonun üzerine çıkması, gelirin ise 60 milyon doları geçmesi beklenmektedir (Yılmaz 2020). 2021 yılında küresel aktörlerden Discovery, BluTV'nin \%35'ni almıştır (Clever 2021). ${ }^{13}$

Sinema salonlarının kapalı kalması yapımcıları dijital platformlara yönlendirmiştir. Sinemaların kapanması sonucu gösterimi ertelenen filmlerden 9 Kere Leyla (Ezel Akay 2020), yeniden açılan salonlara seyircinin gelmemesi üzerine dijital platformlara, Netflix'e satılmıştır. Sinema salon gösterimi atlanarak doğrudan dijital platformlara yönelme olmuştur. Benzer bir durum Taylan kardeşlerin Azizler filmi için de söz konusudur. Azizler sinema salon gösterimini yapmadan 8 Ocak 2021 itibariyle dijital platform üzerinden seyirciyle buluşmuştur. K20 bu tercihlerin nedeni olarak "yapımcıların önlerini görememeleri ve filmin ekonomik döngüsü için dijital platformları tercih ettiklerini" belirtmektedir. Netflix ayrıca doğrudan kendisinin yapımcılığını üstlendiği film projelerine de Türkiye' de başlamıştır: Kağıttan Hayatlar (Can

Dijital platformlar üzerine yapılan bir araştırma eğilimleri göstermesi açısından önemli veriler içermektedir. Marketing Türkiye'nin Xsights Araştırma Şirketi'ne yaptırdığ 1 “Dijital Yayın Platformları" araştırma verilerine göre araştırmaya katılan 500 katılımcının tamamı dijital yayın platformlarına üyedir. Dijital platformları tercih etme sebeplerinin başında \%73 ile "iyi içerik" ve "esnek saatlerde izleyebilme" (dilediği içeriği, dilediği saatte izleyebilme) olanakları gelmektedir. Daha az reklam olması sebebiyle dijital platformları tercih edenlerin oranı ise $\% 55$. Yüksek görüntü kalitesi nedeniyle tercih edenlerin oranı $\% 47^{\prime}$ dir. Kullanımının kolay olması \%40 ve dil seçeneği sunma özelliği ise \%32'dir. Araştırmaya katılan kullanıcıların büyük bir bölümünün iki farklı platformda üyeliği bulunmaktadır. Araştırmaya göre, en az bir dijital platforma üyeliği bulunanların \%73'ü Netflix kullanmaktadır. \%21 ile BluTV ikinci ve Amazon Prime Video \%14 ile üçüncü sırada yer almaktadır (Yıldız 2021). 
Ulkay 2021), Sen Hiç Ateş Böceği Gördün mü? ${ }^{14}$ (Andaç Haznedaroğlu, 2021), Yarına Tek Bilet (Ozan Açıktan 2020), Beni Çok Sev (Mehmet Ada Özteki 2021) (Netflix Türkiye, Yeni Yerli Projelerini Duyurdu 2020).

Küresel dijital aktörlerin yerli yapım ve dizileri dünyaya açmaları ayrı bir tartışma konusunu oluşturmaktadır. Bu konuda en önemli örneği 7. Koğuştaki Mucize (Mehmet Ada Özteki 2019) filmi göstermiştir. Film, eve kapanmaların yaşandığı dönemde Netflix ABD ve Fransa listelerinde ilk onda yer almıştır (7. Koğuştaki Mucize 2020) Bir başka örnek ise Türkiye' de büyük tartışmalar yaratan Netflix dizisi Bir Başkadır'ın Almanya, İsviçre, Romanya, Bulgaristan'da ilk ona girmesidir (Doğan 2020). Bu başarılar, yerli dizi ve filmlerin küresel pazara açılmaları konusunda dijital platformların önemli bir aktör olacağını göstermektedir. Organize İşler Sazan Sarmalı filminin Netflix'te gösterilmesinin yarattığ1 tartışma sırasında BKM tarafından yapılan açıklamada vurgu dünyaya açılmak "dünya seyircisi ile buluşmak (...) dünyanın her yerinde yaşayan sinema seyircisine ve yurttaşlarımıza izletmek imkânı" üzerinedir (Sazan Sarmalı Netflix'te 2019). Katılımcılardan K5'in bu konuda çekinceleri vardır. 7. Koğuştaki Mucize başarısının Güney Kore uyarlamasına bağlı olduğunun altını çizerek "Gerçekten bir açılım getirebilecekler mi bekleyip görmek lazım” ifadesi ile kuşkularını belirtmiştir. ${ }^{15}$

Dijital platformlarla birlikte yapımcılık modelinde değişim olacağına ilişkin görüşler ise katılımcılar tarafından şöyle ifade edilmiştir: “Dijital platformlar yapım açısından sektörde olumlu bir gelişme, işin başı-sonu belli, elit bir duygu veriyor" (K9). “Dijital platformlar için küçük bütçeli işler yapmak lazım; bambaşka bir tasarım” (K31). "Tecimsel yapımlar dijital projelere yöneliyorlar" (K26). Kriz sırasında yapımcıların yüzünü dijital platformlara döndüğü, bunun da değer zincirinde değişimlere neden olacağı öngörülmektedir.

Dijital platformların yükselişi ve sinema salonlarının pandemiden dolayı kapatılması sinema salonlarında daralma yaşanacağına dair bir izlenim oluşturmuştur. COVID-19 pandemisi sürecinde sinema salonlarının kapanması, eve kapanma ve sosyal mesafe koşulları nedeniyle dijital platformlara yönelim gerçekleşmiştir. Bu yönelim, "seyircinin tercih ve alışkanlıklarında değişimlere neden olacağ1"nı düşündürmüş (K31) ve seyircinin sinema salonlarına -・・

14 Yılmaz Erdoğan'ın sahnelendiği yıllarda ödül ve gişe rekortmeni olan tiyatro oyununun modern uyarlamasıdır.

15 Bu süreçte Türkiye dizi ihracatında Hollywood'dan sonra dünya ikincisi olarak değerlendirilmektir (DW Türkçe 2021). 
geri dönüp dönmemesi konusunda endişelere yol açmıştır. “Dijital platformların yükselişinin, sinema salonlarının kapanmasına yol açacağı kaygısı"nı güçlendirmiştir (K20, K28, K10). K28 sinemadaki değişimi şu sözlerle ifade eder: "Medya yön değiştiriyor, sinema bitmez, mecrası değişiyor. Eğer böyle giderse \%40-50 salon kapanabilir." Sinema salonlarının kapanmasında dijital platformların yükselişinin de etkisi olduğu sektörde genel bir uylaşımdır. Buna karşın sağlık krizi bittiğinde, seyircinin en temel sosyalleşme mecrası olarak sinema salonlarına döneceği de genel bir beklentiyi yansıtmaktadır: "Pencere aralıkları tartışmalı, pencere aralığı iyi tutulsa sorun yok. Sinema video kasete, televizyona, DVD'ye, home theather'a direndi, dijital platformlara da direnir. Gençlerin sosyalleşebileceği en ucuz eğlenceyi ve ortamı sunuyor sinema çünkü. Arkadaşlar, sevgililer, aileler sinemaya gelecek" (K35). "Çok salon kapanacak ama sosyalleşme mekânı olarak devam edecek" (K30). “Dijital platformlar karantinada alışkanlığa dönüştü" (K26). Derinlemesine görüşmelerde, özellikle ABD'de stüdyoların eğilimlerinin dijital platformlar ve sinema sektörü arasındaki ilişkileri belirlemede öncü olacağı belirtilmektedir: "Stüdyolar baktılar seyirci sinemaya gelmiyor, onlar hazır seyircinin ayağına gittiler" (K23).

Sektörde bir diğer tartışmalı konu, pencereler ve erteleme sürelerinin yönetmelikle düzenlenmesi ve pandemi sırasında revizyona gidilmemesi olmuştur. 22 Ekim 2019 tarihinde yürürlüğe giren Sinema Filmlerinin Değerlendirilmesi ve Sınıflandırılmasına İlişkin Usul ve Esaslar Hakkında Yönetmelik'in ilgili maddesi şöyledir: ${ }^{16}$

Madde 10(2): Sinema salonlarında ilk kez ticari dolaşıma girecek değerlendirme ve sınıflandırması yapılmış sinema filmleri, gösterime girdiği tarihten itibaren ücretli yayın yapılan kablo, uydu, karasal, internet ve diğer ortamlarda beş ay geçmeden, ücretsiz yayın yapılan uydu, karasal, internet ve diğer ortamlarda altı ay geçmeden ticari amaçla yayınlanamaz veya umuma iletilemez.

İşletmeciler bu sürenin uzatılmasını isterken, özellikle bağımsız yapımc1lar bu sürenin uzun olduğunu, mücbir sebepler nedeniyle serbest birakılması gerektiğini ayrıca bu düzenlemenin sektörel teamüllerle çözümlenmesi gerektiğini ifade etmektedirler (K33, K34). SISAY, pencereler arası ertelenme süresinin 11 veya 12 aya çıkarılmasını istemektedir (Box Office Türkiye 2020b). Ana akım bir yapımcı K23, erteleme süreleri için "yasal düzenleme yapılması ve cezai işlemlerin de konulması" gerektiğini belirtmektedir. Bağımsız ya-..

16 https://www.resmigazete.gov.tr/eskiler/2019/10/20191022-8.htm 
pımcı K33 ise bu duruma tepkisini şöyle ifade etmektedir: "Bağımsız yapımcı sinemalarda bir hafta gösterim şansı buluyor. 12 ay bekleyecek. Bu durumda sinema salon gösterimini doğrudan pas geçer, dijital platforma giderim." Bir diğer bağımsız yapımcı K34 ise "Avrupa'da pandemiden dolayı bu süre daha kısalıyor" diyerek pandemi krizinde erteleme sürelerinin esnetilebileceğine dikkat çekmektedir. Şu anki yasal düzenleme bağımsız sinemacılar tarafından sorunlu olarak değerlendirilmiştir (K33). "Sinema salonu için ilk gösterim çok önemli" (K7). "Sinemacı asıl geliri salondan elde eder. Diğer gelirler (TV, dijital platform) sektör deyimiyle kaymak olur" (K31). Bu anlaşmazlıklar sinema yasasının revizyonunu gündeme getirebilir. $\mathrm{Bu}$ düzenlemede ifade edilen tarih aralıklarının söz konusu pandemi sürecine bağlı olarak yeniden gözden geçirilmesi gerekmektedir. Türkiye' de bir diğer yasal düzenleme lisanslama boyutunda yapılmıştır. Ağustos 2019'da çıkarılan Radyo, Televizyon ve İsteğe Bağlı Yayınların İnternet Ortamından Sunumu Hakkında Yönetmelik ile Radyo ve Televizyon Üst Kurulu'na (RTÜK) Türkiye'deki çevrimiçi radyo, TV ve isteğe bağlı yayıncılığı düzenleme ve denetleme yetkisi verilmektedir. ${ }^{17}$ Bu kapsamda RTÜK, Türkiye'de faaliyet göstermeleri için Netflix ve Amazon Prime Video'ya on yıllık lisans vermiştir.

\section{Tartıșma ve Sonuç}

COVID-19 pandemisi sinema endüstrisinde 5-10 yıl içinde beklenen yapısal değişikliklerin çok hızlı ve beklenmedik biçimde çok kısa bir sürede gerçekleşmesine neden olmuştur. COVID-19 pandemisi, sinema sektöründeki yeni yapılanma ve işleyiş bağlamında katalizör işlevi görmüştür. COVID-19 krizi ve buna bağlı olarak ortaya çıkan mali yük, dijital platformları cazip hale getirmiştir. Böylece COVID-19 pandemisi, film dağıtımında orta ve uzun vadede yapısal bir değişimi hızlandırmaktadır. Bu durumun hem seyir pratiğinde değişimler getireceği, hem de sinema salonu cephesinde bir küçülmeye neden olacağı öngörülmektedir. Dijital platformların yükselişi dünyada da gözlenen bir eğilim olmasına karşın pandemi, süreci hızlandırmıştır. Bu durum sinema değer zincirinde ciddi değişimlere neden olmaktadır. Dijital platformların yükselişi nedeniyle geleneksel pencere sistemi yapıları üzerine inşa edilen geleneksel dağıtım değer zincirinin dikey bağlantıları sorgulanmaya başlanmıştır. Yeni iş stratejileri, yeni çalışma pratikleri geliştirmek zorunluluğu doğ-

17 https://www.resmigazete.gov.tr/eskiler/2019/08/20190801-5.htm. Bu yönetmelik kapsamında RTÜK istemleri doğrultusunda Netfix, Designated Survivor adlı dizinin bir bölümüne erişimi kaldırmış, Şimdiki Aklım Olsaydı dizi projesini ise iptal etmiştir. Bu durum sansür olarak değerlendirilmiştir (Yücel 2020). 
muştur. Dijital dağıtımın, yapımcılara kullanım üzerinde daha fazla kontrol, hedef kitlelerine ulaşmada daha fazla başarı sağlaması yüzünden yapımcıların ve stüdyoların pandemi sürecinde çabuk adaptasyon sağladıkları gözlemlenmiştir. Bağımsız film yapımcıları ise interneti daha demokratik bir dağıtım platformunun geleceği olarak görmektedirler (Vitkauskaitė 2020). Sinema dağıtım ağı öncelikle karma bir paradigma izleyecek, uzun dönemde ise seyirci sayısı, sektörel uylaşımlar ve yasal düzenlemelere göre şekillenecektir. Önümüzdeki süreçte dijital platformların değer zinciri içindeki yerini belirleyecek temel dinamikler ise şunlardır:

1. Sinema dağıtım penceresi aracılığıyla üretilen dünya çapında tarihsel gişe getirileri ve bunun, talebe bağlı video platformlarından elde edilen potansiyel gelirle karşılaştırılması.

2. Sinema salonu gösterimlerini destekleyen pazarlama harcaması düzeyi ve doğrudan tüketiciye yönelik bir model kapsamındaki etki (Kerr ve Cyba 2020, 5).

3. ABD' de film bütçesi içinde oldukça yüksek bir oranı (\%30-35) oluşturan baskı ve reklam/tanıtım maliyetlerindeki düşüş de bu konudaki belirleyiciler olacaktır (Kerr ve Cyba 2020; K5).

Sinema salonlarında seyirci sayısının düşüşü önlenemezse (bunda önemli faktörler bilet fiyatlarının yüksekliği ve korsan sorunudur) sinema gösteriminin özel bir iş haline gelebileceğinden endişe edilmektedir. Dijital platformların küresel olarak gelişimi, seyir deneyimi ve seyirci profilindeki değişimler açısından endişeler de doğurmaktadır. Dijital platformların internet erişim ve abone sisteminin kentli orta sınıf bir seyirci yaratacağı ve alt sınıftan insanların sinemaya erişim konusunda sorunlar yaşayabileceği ve bu nedenle geniş bir kitlenin sinemadan mahrum kalacağı düşünülmektedir (Ray 2020). Dijital platformlar ve seyirci ilişkisi açısından bir diğer endişe de algoritma ve katalogların seyirciyi müşteriye dönüştüreceği ve farklı bir sinema kültürü yaratacağı üzerinedir. Bunun yanında platformların sinefiller (Shambu 2020) ve aileler için önemi de ortadadır. Platformlar, sinefillere istedikleri filmlere istedikleri zaman ulaşma ve tekrar tekrar izleme olanağı verirken aileler için daha ucuza daha kolay eğlence olanağı sunmaktadır. Özellikle animasyon sinemasına ucuz ve kolay ulaşım ve tekrar izleme seçenekleri dijital platformları aileler için daha cazip bir hale getirmektedir.

Bu makale, COVID-19 pandemisinin sinema endüstrisinde yaratmış olduğu tartışmaya dijital platformların sinema değer zincirinde ciddi değişim- 
lere neden olduğu konusunda katkıda bulunmaktadır. Çalışma dijital platformlar ve değer zinciri ilişkisini, hem endüstrinin yapısal dönüşümleri hem de yasal düzenlemeler açısından ele almaktadır. Dijital teknolojinin dağıtım ve tüketim değer zinciri faaliyetleri üzerindeki etkisi, pazarı arz odaklı olmaktan talebe dayalı hale getirmektedir. Bu süreç yeni iş modelleri ve stratejilerini ortaya çıkarmaktadır. Dijital platformlar, bağımsız sinema ve belgeseller için uygun bir alternatif olarak değerlendirilirken (Kehoe ve Mateer 2015), internete karşı olduğu ileri sürülen ana akım sinemanın da (Currah 2006) pandemi sürecinde dijital platformlara yöneldiği gözlemlenmiştir. Yeni normal olarak (von Sychowski 2014) görülen dijital platformlar, değer zincirinin asli unsuru olmuştur.

Türkiye özelinde dijital platformların değer zincirindeki payının küresel sinema endüstrisi eğilimlerine paralel olarak süreç içerisinde artacağı öngörülmektedir. Yasal düzenlemeler yapılırken VoD'leri tek bir pencere olarak görmemek, kendi içinde farklı pencere uygulamaları olarak değerlendirmek gerekmektedir. Dijital platformları, sinema salonlarına karşı bir düşman olarak konumlamaktansa, yapılacak yasal düzenlemelerle sinema sektörünü destekleyen bir mecraya taşımak gerekir. Bu çerçevede dijital platformların yıllık gelirlerinin $\% 2$ 'si sinema salonlarına dağıtılmak üzere sinema fonuna aktarılabilir (Erkılıç, Duruel Erkılıç ve Değirmen, 2020). Böylece sinema ekosisteminin yeni koşullar çerçevesinde dönüşerek kendini var etmesi sağlanmiş olacaktır. 


\section{Kaynakça}

Andreeva, Neillie. 2020. "Historian William Mann On How The 1918 Spanish Flu Changed Hollywood Forever \& How COVID-19 Might Too." Deadline. Erişim tarihi 25 Nisan 2020.

https: / deadline.com/2020/04/hollywood-coronavirus-impact-spanish-fluhistory-lessons-william-mann-interview-1202899630/

Ballard, Sam. 2020. “Ōma in Paris Will Be The World's First 'Vertical' Cinema With Private Pods." Erişim tarihi 2 Eylül 2020.

https: / globetrender.com/2020/08/29/oma-paris-vertical-cinema-privatepods/.

Belton, John. 2002. “A False Revolution.” October 100 (Spring): 98-114.

Brecht, Bertolt. 1974. "Film bir meta'dır, sinema bir eğlence." Çeviren İzzet Yasar. Çă̆daş Sinema 1: 50-52.

Box Office Türkiye. 2020a. "Sinema salonları vs. online mecralar: Doğrudan ev sinemasına gelen Trolls World Tour, birçok rekorun yeni sahibi oldu." Erişim tarihi 20 Nisan 2020.

https: / / boxofficeturkiye.com/haber/sinema-salonlari-vs-online-mecralardogrudan-ev-sinemasina-gelen-trolls-world-tour-bircok-rekorun-yeni-sahibioldu--2571

Box Office Türkiye. 2020b."Sinemada normalleşme süreci 6 aydan uzun sürebilir." Erişim tarihi 15 Nisan 2020.

https: / / boxofficeturkiye.com/haber/box-office-turkiye-sinemadanormallesme-sureci-6-aydan-uzun-surebilir--2568

Brody, Richard. 2020. "Lessons for the Movie Industry from the 1918 Influenza Pandemic." New Yorker. Erişim tarihi 20 Nisan 2020.

https: / / www.newyorker.com/culture/the-front-row / lessons-for-the-movieindustry-from-the-1918-influenza-pandemic.

Cherchi Ushai, Paolo. 2001. The Death of Cinema. Londra: BFI.

Comolli, Jean-Luc ve Paul Narboni. 1989. "Cinema/Ideology/Criticism”. Cahiers du Cinéma, 1969-1972: The Politics of Representation içinde, editör Nick Browne, 5867. Cambridge: Harvard University Press.

Cunat, Lea. 2019. “European Public Broadcasters' Future Investment in Original Content Challenged." Ampere Analysis. Erişim tarihi 20 Ağustos 2020. https://www.ampereanalysis.com/insight/european-public-broadcastersfuture-investment-in-original-content-challenged 
Currah, Andrew. 2006. "Hollywood versus the Internet: the media and entertainment industries in a digital and networked economy." Journal of Economic Geography 6: 439-468.

Davies, Adam ve Nicaol Wistreich. 2007. The Film Finance Handbook, New GlobalEdition. Londra: Netribution.

D’Alessandro, Anthony. 2020a. “Universal \& AMC Theatres Make Peace, Will Crunch Theatrical Window To 17 Days With Option For PVOD After." Erişim tarihi 1 Ağustos 2020.

https: / / deadline.com/2020/07/ universal-amc-theatres-theatrical-windowcrush-pvod-agreement-1202997573/.

D’ Alessandro, Anthony. 2020b. “Cinemark Boss Mark Zoradi On Universal-AMC Deal: 'Aggressive Shortened Theatrical Window Could Have An Adverse Impact' To Movie's Life." Erişim tarihi 5 Ağustos 2020.

https:// deadline.com/2020/08/ cinemark-mark-zoradi-on-universal-amctheater-window-collapse-1203003411/.

D' Alessandro Anthony. 2021. “Mission: Impossible 7' \& 'A Quiet Place Part II' To Hit Paramount+ After 45-Day Theatrical Run." Deadline Erişim tarihi 26 Şubat 2021.

https: / / deadline.com/2021/02/ mission-impossible-7-a-quiet-place-part-ii-tohit-paramount-after-45-day-theatrical-run-1234700304/

D’Alessandro, Anthony ve Nancy Tartaglione. 2020. “Cineworld Reacts To UniversalAMC Theatrical Window Crunching PVOD Deal: We Do Not See Any Business Sense In This Model." Erişim tarihi1Ağustos 2020. https: / / deadline.com/2020/07/ cineworld-universal-amc-theatricalwindows-pvod-deal-1202998245/.

Dikkol, Selver. 2020. “Türkiye'de Blu TV Deneyimini Ekonomik ve Sembolik Sermaye Bağlamında Okumak." Gümüşhane Üniversitesi İletişim Fakültesi Elektronik Dergisi (e-gifder) 8 (1): 478-502.

Doğan, Ömer Faruk. 2020. “Bir Başkadır, Almanya'da en çok izlenenler listesine girdi.” Erişim tarihi 25 Kasım 2020.

https: / / hwp.com.tr/bir-baskadir-almanya-en-cok-izlenenler-listesinegirdi-159968.

Dziadul, Chris. 2021. “Netflix starts 2021 on a roll." Erişim tarihi 25 Ocak 2021. https: / / www.broadbandtvnews.com/2021/01/20/netflix-starts-2021-on-aroll $/$ ?mc_cid=a520f727dd\&mc_eid=7a57aef086

DW Türkçe. 2021. "Türkiye dizi ihracatında Hollywood'dan sonra dünya ikincisi." Erişim tarihi 20 Haziran 2021. https://www.youtube.com/watch?v=g07tFkijtt4. 
Eliashberg, Jehoshua, Anita Elberse ve Mark Leenders. 2006. “The Motion PictureIndustry: Critical Issues in Practice, Current Research, and New Research Directions." Marketing Science 25(6):638-661.

Erem, Onur. 2019. “Sinema yasası: Neden tartışılıyor, yeni yasa çözüm olacak mı?” Erişim tarihi 23 Ocak 2019. https:// www.bbc.com/turkce/haberler-turkiye-46925169,

Erkılıç, Hakan. 2017."Dijital Sinema Teorisi Üzerine: Akışkan Sinema ve Akışkan Sinema Teorisi." SineFilozofi 2(4): 56-72.

Erkılıç, Hakan, Senem Duruel Erkılıç ve Süleyman Değirmen. 2020. COVID-19 Pandemisi ve Sinema Sektöründe Kriz- TÜBITAK-SOBAG COVID-19 ve TOPLUM 120K625 PROJESİ.

Erkılıç, Hakan ve Ayşe Gül Toprak. 2012. “Belgesel sinemanın alternatif dağıtım ve gösterim olanağı olarak internet." The Turkish Online Journal of Design Art and Communication 2(2): 10-16.

Finney, Angus. 2010. The International Film Business. Londra: Routledge.

Finney, Angus. 2014. Brave New World an Analysis of Producer / Distribution Joint Ventures. A report commissioned by Film Cymru Wales and Creative Skillset. Erişim tarihi 23 Kasım 2020.

https: / filmresearch.org/assets/pdf/251.pdf

Finney, Angus. 2015. The International Film Business: A Market Guide Beyond Hollyvood. New York: Routledge.

Gaudreault, André ve Phillippe Marion. 2015. The End of Cinema. Çeviren Timothy Barnard. NewYork: Columbia University Press.

Gaudreault, André ve Phillippe Marion. 2020. Kinematik Dönemeç. Çeviren Can Gündüz.. Eskişehir: Yort.

Jenkins, Henry. 2006. Convergence Culture: Where Old and New Media Collide. New York: UP.

Kaynak, Alev. 2019. “Algoritmalar iyi gün dostu..." digitalage 128: 62-63.

Kehoe, Keith ve John Mateer. 2015. “The Impact of Digital Technology on the Distribution Value Chain Model of Independent Feature Films in the UK." International Journal on Media Management 17:2, 93-108, DOI: 10.1080/14241277.2015.1055533

Kerr, Maureen ve Denis Cyba. 2020. "The Economics of film changing dynamics and the COVID-19 world." FTI Consulting. Erişim tarihi 11 Eylül 2020. https:/ / www.fticonsulting.com/insights/articles/economics-film-changingdynamics-covid-19-world 
Kovach, Steve. 2020. "Your movie theater experience is going extinct." CNBC. Erişim Tarihi 26 Aralık 2020.

https:// www.cnbc.com/2020/12/04/ warner-bros-to-release-movies-on-hbomax-threatening-theatrical-windows.html.

Kostovska, Ivana, Tim Rats ve Karen Donders.2020. "The rise of the 'Netflix tax' and what it means for sustaining European audiovisual markets." Innovation: The European Journal of Social Science Research 33(4): 423-441. DOI: $10.1080 / 13511610.2020 .1774354$

Küng, Lucy. 2008. Strategic management in the media: Theory and practice. Londra: SAGE Publications.

Leiva, Garcia, M T. ve A. Luis Albornoz. 2020. "VOD service providers and regulation in the European Union: an audiovisual diversity approach." International Journal of Cultural Policy 180 (1): 101-115. DOI: 10.1080/10286632.2020.1769614

Lobato, Ramon. 2019. Netflix Nations. NewYork: NewYork University Press.

Lodge, Guy. 2020. “Tenet didn't just fail to save cinema - it may well have killed it for good." Erişim tarihi 5 Ekim 2020.

https: / www.theguardian.com/ film/2020/oct/06/ tenet-didnt-just-fail-tosave-cinema-it-may-well-have-killed-it-for-good.

Meikle, Graham ve Sherman Young. 2012. Media Convergence: Networked Digital Media in Everyday Life. Palgrave-Macmillan

Meares, Hadley. 2020. "Closed Movie Theaters and Infected Stars: How the 1918 Flu Halted Hollywood." Erişim tarihi 1 Nisan 2020. Hollywood Reporter. https: / www.hollywoodreporter.com/news/how-1918-flu-haltedhollywood-1286640.

Murdock, Graham. 2000. “Digital Futures: European Television in the Age of Convergence." Television Across Europe içinde, editörler Jan Wieten, Graham Murdock ve Peter Dahlgren. London: Sage.

“Netflix Türkiye, Yeni Yerli Projelerini Duyurdu.” 2020. Erişim tarihi 25 Ekim 2020. https: / / altyazi.net/haberler/netflix-turkiye-yeni-yerli-proje-duyurusu/.

Nilsen, Anders Waage ve Rune Smistad. 2012. "ICT challenges and opportunities for the film industry - a value chain perspective on digital distribution." Erişim tarihi 17 Ekim 2019.

http:/ / archive.northsearegion.eu/files/repository/20140903172212 valuechain-perspective-on-digitaldistribution.pdf.

“O karar ortalığı karıştırdı... Çok sert tepki geldi.” 2019. Erişim tarihi 20 Şubat 2019. https: / / www.hurriyet.com.tr/gundem/o-karar-ortaligi-karistirdi-cok-serttepki-geldi-41120295. 
Pardo, Alejandro. 2014. “Digital Hollywood: How internet and social media are changing the movie business." Handbook of Social Media Management: Value Chain and Business Models in Changing Media Markets içinde, editörler M. Friedrichsen ve W. Mülh-Benninghaus, 329-348. New York: Springer.

Pulver, Andrew. 2020. "At least 170,000 lose jobs as film industry grinds to a halt due to coronavirus." The Guardian. Erişim tarihi 25 Mart 2020.

https: / / www.theguardian.com/film/2020/mar/19/loss-of-jobs-income-filmindustry-hollywood-coronavirus-pandemic-covid-19.

Ray, Kunal. 2020. “Cinema after COVID-19.” Erişim tarihi 14 Haziran 2020. https: / / www.thehindu.com/opinion/op-ed/ cinema-after-covid-19/ article31643937.ece

Rubin, Rebecca. 2021. “U.S. Box Office Plummets 80\%, Global Revenue Drops 71\% in 2020 Amid Pandemic." Erişim tarihi 15 Ocak 2021. Variety. https: / / variety.com/2021/ film/box-office/ box-office-final-revenues-2020coronavirus-pandemic-1234879082/

Salvador Elisa, Jean Paul Simon ve Pierre Jean Benghozi. 2019. “Facing Disruption: The Cinema Value Chain in the Digital Age." International Journal of Arts Management 22(1): 25-40.

“Sazan Sarmalı Netflix'te gösterime girince ortalık karıştı!” 2020. Cumhuriyet. 16 Şubat 2019.

https:// www.cumhuriyet.com.tr/haber/sazan-sarmali-netflixte-gosterimegirince-ortalik-karisti-1251581

Schwartzel, Erich. 2020. "Trolls World Tour' breaks digital records and charts a new path for Hollywood." Wall Street Journal. Erişim tarihi 2 Mayıs 2020.

https:/ / www.wsj.com/articles/trolls-world-tour-breaks-digital-records-andcharts-a-new-path-for-hollywood-11588066202.

Scorsese, Martin. 2021. "Federico Fellini and the lost magic of cinema." Harper's Magazine. Erişim tarihi 20 Şubat 2021.

https:/ / harpers.org/archive/2021/03/il-maestro-federico-fellini-martinscorsese/

Shambu, Girish. 2020.Yeni Sinefili. Çeviren Bilge Demirtaş. Eskişehir: Yort.

Spangler, Todd. 2020. "YouTube to Host Free Virtual Film Festival With 20 Partners Including Cannes, Tribeca, Sundance." Erişim tarihi 12 Mayıs 2020. https://variety.com/2020/digital/news/youtube-free-film-festival-cannestribeca-sundance-1234590501/

Stevens, Kristen. 2016. Australian Film Festivals. NewYork: Palgrave Macmillan. 
Strauven, Wanda. 2020. “Let's Go to Oberhausen! Some Notes on an Online Film Festival Experience." Pandemic Media. Erişim tarihi 25 Ağustos 2020. https: / / pandemicmedia.meson.press/chapters/education-instruction/letsgo-to-oberhausen-some-notes-on-an-online-film-festival-experience/

Swartz, Jon. 2020. "Netflix has biggest quarter with nearly 16 million new subscribers signing on." Erişim Tarihi 30 Nisan 2020.

https: / / www.marketwatch.com/story/netflix-adds-more-than-15-millionnew-subscribers-stock-rockets-higher-2020-04-21?mod=article_inline.

Troyn, Chuck. 2013. On-Demand Culture. New Jersey: Rutgers University Press

Turner, Graeme. 1999. Film as Social Practice. Londra: Routledge.

Ulin, Jeffrey C. 2010. The Businness of Media Distrubition. Oxford: Elsevier.

UNESCO. 2020. Culture in Crisis: Policy Guide for a Resilient Creative Sector. Erişim tarihi 26 Aralık 2020.

https://unesdoc.unesco.org/ark:/48223/pf0000374631.

Vanacker, Rebecca. 2020. “Scoob! Tops Premium VOD Charts Faster Than Trolls World Tour." Screen Rant. Erişim tarihi 3 Haziran 2020. https:/ / screenrant.com/scoob-beats-trolls-world-tour-vod-charts/.

Vang, Jan ve Cristiana Chaminade. 2007. “Cultural Clusters, Global-Local Linkages and Spillovers: Theoretical and Empirical Insights from an Exploratory Study of Toronto's Film Cluster." Industry and Innovation 14(4): 401-420.

van Dijck, José, Thomas Poell ve Martijn de Waal. 2018. The Platform Society. NewYork: Oxford University Press.

Vary, Adam B.ve Rebecca Rubin. 2020. “With ‘Mulan,' Disney Tests Out Entirely New Early VOD Model." Erişim tarihi 6 Ağustos 2020.

https:/ / variety.com/2020/ film/news/mulan-disney-pluspremiere-1234711185/.

Vitkauskaitè, Ieva. 2020. “Types of Film Production Business Models and Their Interrelationship." Informacijos Mokslai 89:43-54.

von Sychowski, Patric. 2014. "Premium VOD just killed the cinema release window." Celluloid Junkie. Erişim tarihi 10 Haziran 2020.

https: / celluloidjunkie.com/2014/06/03/ premium-vod-just-killed-cinemarelease-window/

Vulser, Nicole. 2020. “Plan de Relance :Roselyne Bachelot Détaille la Répartition des Aides au Cinéma." Le Monde. Erişim tarihi 26 Aralık.2020.

https: / / www.lemonde.fr/ cinema/article/2020/09/23/plan-de-relanceroselyne-bachelot-detaille-la-repartition-des-aides-au-cinema_6053348_3476. $\underline{\mathrm{html}}$ 
Walsh, Joe.2020. "Netflix Subscriber Growth Slows After Surging During Pandemic." Erişim Tarihi 24 Ekim 2020.

https:/ / www.forbes.com/sites/joewalsh/2020/10/20/netflix-subscribergrowth-slows-after-surging-during-pandemic/?sh=62db06ac244

Westcott, Kevin vd. 2020. Digital Media Trends Survey, 14th edition. Erişim tarihi 5 Ağustos 2020.

https:/ / www2.deloitte.com/content/dam/insights/us/articles/6456 digital-media-trends-covid/DI Digital-media-trends-14th-edition.pdf.

Yavuz, Deniz. 2020a. “2020 yılında, sayılarla Türkiye sinema vizyonu.” Antrakt Sinema. Erişim tarihi 9 Aralık 2020. https: / / www.antraktsinema.com/makale.php?id=811

Yavuz, Deniz. 2020b. “Tenet'in Türkiye serüveni." Antrakt Sinema. Erişim tarihi 9 Aralık 2020.

https: / / www.antraktsinema.com/makale.php?id=810

“7. Koğuştaki Mucize ABD ve Fransa'da Netflix'ten en çok izlenen film oldu”. 2020. Cumhuriyet, 6 Nisan 2020.

https: / / www.cumhuriyet.com.tr/haber/7-kogustaki-mucize-abd-vefransada-netflixten-en-cok-izlenen-film-oldu-1731471.

Yıldız, Gizem. 2021. “Kurtlar sofrasında kazanan dijital yayın platformu hangisi?” Marketing Türkiye. Erişim tarihi:20 Şubat 2021.

https://www.marketingturkiye.com.tr/haberler/dijital-yayinplatformlarinda-rekabet-kizisiyor

Yılmaz, Mustafa Cihan.2020. “Netflix'in Türkiye'deki ve Dünyadaki Abone Sayıs1 Belli Oldu." Erişim tarihi 3 Temmuz 2020.

https:// www.webtekno.com/netflix-turkiye-abone-sayisi-belli-oldu-h95042. $\underline{\mathrm{html}}$

Yılmaz, Zafer. 2020. “Doç. Dr. Hakan Erkılıç: “Dijital Platformların Yükselişini Dillendirmek Sinemaya İhanet Değil." SineBlog. Erişim tarihi 18 Haziran 2020. http:/ / sineblog.org/ozel-soylesi-doc-dr-hakanerkilic-dijital-platformlarinyukselisini-dillendirmek-sinemaya-ihanet-degil/

Yücel, Fırat. 2020. “Bakanlık ve RTÜK'ten Sansür, Netflix'ten İptal Kararı.” Erişim tarihi 28 Temmuz 2020.

https:/ / fasikul.altyazi.net/ pano/bakanlik-ve-rtukten-sansur-netflixten-iptalkarari/.

Yücel, Fırat ve Enis Köstepen. 2020. “Sinema Nereye?” Erişim Tarihi 25 Ağustos 2020. https:/ / fasikul.altyazi.net/video/fasikul-tartismalari/sinema-nereye/. 